\title{
NASIONALISME INDONESIA: NASIONALISME PANCASILA
}

\author{
Oleh: Miftahuddin*
}

\begin{abstract}
Abstrak
Tentu saja semua masyarakat bangsa ini tidak mau dikatakan sebagai orang yang "munafik", yaitu orang yang mengingkari nilai-nilai yang pernah dicita-citakan, dirumuskan, dan ditegakkan para pendahulu. Dalam hal ini, memperoleh kemerdekaan dan menegakkan harga diri bangsa adalah cita-cita yang pernah diperjuangkan oleh para pendiri bangsa ini. Namun, apa yang terjadi tampaknya cita-cita yang telah terwujud itu sekarang telah diingkari. Sebagian di antara kita telah menjadi orang yang "munafik", sehingga harga diri kita sebagai suatu bangsa seakan-akan telah hilang dan bahkan senang menjadi bangsa yang “didhalimi dan dijajah”. Dalam rangka mengkritisi perilaku yang selama ini tampak melenceng, artikel ini akan mengajak semua komponen untuk menengok kembali sejarah, sehingga dapat dilihat ternyata betapa luhurnya perjuangan para pendiri bangsa ini karena mereka telah menegakkan nilai-nilai yang luhur yang tampak tercermin dalam Pancasila. Demikian pula, dengan melihat sejarah akan kelihatan, betulkan jiwa nasionalisme sudah tertanam dalam pribadi sebagai bangsa Indonesia, atau ternyata kita hanyalah menjadi orang yang munafik.

Kenyataannya banyak dari komponen bangsa ini telah mengingkari nilainilai Pancasila, sehingga sulit untuk dikatakan sebagai golongan yang berjiwa nasionalisme. Betapa tidak, bukankah sebagian masyarakat telah mementingkan dirinya sendiri, misalnya, dengan melakukan praktek korupsi atau melakukan apa pun demi memperoleh keinginannya, misalnya kekuasaan. Demikian pula, ternyata pemerintah bangsa ini tidak mempunyai kekuatan, sehingga membiarkan dan bahkan memberi kesempatan bangsa lain untuk mendhalimi dan menindas. Butul bahwa penjajahan dalam bentuk fisik sudah enyah dari bangsa ini, akan tetapi bukankah neokolonialisme telah tumbuh yang sebenarnya lebih menyakitkan, karena seolah-oleh bangsa ini tersiksa dalam waktu yang lama dan tidak segera menemukan kesembuhan..
\end{abstract}

Kata Kunci: Didhalimi, munafik, nasionalisme, neokolonialisme, korupsi, Pancasila, dan sejarah.

Suatu bangsa terbentuk dari pengalaman bersama di masa lampau. Hal ini berarti bahwa sejarah "bersama”lah yang membentuk suatu nasion. Untuk menjelaskan keberadaan nasion masa kini, terutama sebagai produk proses historis, implikasi logisnya adalah bahwa perlu dipakai integrasi selaku paradigma. Oleh karena itu, jelaslah bahwa pada hakekatnya sejarah menjadi esensi bagi nasion, sehingga pengetahuan sejarah menjadi dasar pendidikan nasion. Dengan demikian, tidak berlebih-lebihan apabila Sejarah Nasional sebagai cerita tentang

*Staf Pengajar Prodi Ilmu Sejarah, Jurusan Pendidikan Sejarah, FISE UNY. 
pengalaman kolektif di masa lampau sangat strategis kedudukannya dalam pendidikan warga negara. ${ }^{1}$

\section{A. Pendahuluan}

Jika seluruh komponen bangsa Indonesia mengamalkan dengan benar nilai-nilai yang terkandung dalam Pancasila, dapat dikatakan bahwa tidak ada permasalahan yang tidak dapat diselesaikan, terkait dengan kehidupan berbangsa dan bernegara. Demikian pula, apabila semua warga Indonesia dan khususnya para pemegang kebijakan yang diposisikan sebagai panutan bangsa ini menjalankan nilai-nilai yang terkandung dalam Pancasila, bisa jadi bangsa ini akan terhindar dari berbagai permasalahan, misalnya perpecahan atau disintegrasi, penjualan aset-aset negara, demokrasi klise, kemiskinan, korupsi, ketergantungan pada Bank Dunia dan IMF, dan tentu bangsa ini akan menjadi bangsa yang berwibawa dan mandiri. Melihat fenomena sekarang ini, mestinya perlu dipertanyakan betulkah rasa dan nilai nasionalisme sudah benar-benar diamalkan dalam bentuk perbuatan dan tidak hanya dikatakan dalam lisan.

Tampaknya, bangsa ini masih harus banyak lagi belajar dari sejarah. Bangsa ini harus belajar dari sejarah bagaimana pada masa lalu nasionalisme dapat dibangun yang akhirnya dapat menjadi alat melepaskan diri dari belenggu penjajahan, sehingga dapat menjadi suatu negara yang mempunyai wibawa dan merdeka, dengan terwujudnya dasar negara, yaitu Pancasila. Mengapa sekarang bangsa ini berada dalam ancaman perpecahan, menjadi budak Bank Dunia dan IMF, dan kesenjangan yang terus terjadi sehingga kemiskinan tampak sulit dicari

\footnotetext{
${ }^{1}$ Sartono Kartodirdjo, (2003), Multidimensi Pembangunan Bangsa: Etos Nasionalisme dan Negara Kesatuan, Yogyakarta: Kanisius, hlm. 22-23.
} 
obatnya. Betulkah semua itu karena kebanyakan masyarakat tidak mau belajar dari sejarah, belum melaksanakan nasionalisme yang sejati, dan belum mengamalkan Pancasila dengan benar. Untuk itu, tulisan ini mencoba menawarkan terapi terhadap bangsa ini yang tampak sedang sakit dan menghadapi banyak masalah, yaitu bagaimana agar semua komponen bangsa ini sadar untuk berjiwa nasionalisme yang benar sesuai dengan cita-cita para pendiri bangsa sehingga tidak menginkari nilai-nilai Pancasila. Bangsa ini harus sadar, betul bahwa kolonialisme telah hilang dari bumi indonesia, tetapi jangan lupa bahwa kolonialisme telah muncul kembali dalam bentuk yang baru, atau sering disebut neokolonialisme. Untuk itu, tampaknya nasionalisme perlu dibangun kembali, namun tetap berpegang teguh kepada nilai-nilai Pancasila, sehingga tidak menjadikan Pancasila tanpa makna.

\section{B. Nasionalisme Indonesia Versus Kolonialisme}

Berbicara kolonialisme dalam konteks sejarah Indonesia, ia adalah perwujudan dari bentuk keserakahan, ketidakadilan, kebengisan, diskriminasi, dan penafian atas hak asasi manusia. Adapun, jika menengok kebelakang, bahwa bangunan nasionalisme yang pernah ditegakkan oleh para pejuang, pahlawan, dan pendiri bangsa ini, adalah nasionalisme yang anti terhadap kolonialisme, artinya nasionalisme yang terbangun untuk mewujudkan bagaimana bangsa ini merdeka dan bebas dari belenggu kolonialisme. Jadi, telah terbukti bahwa nasionalisme Indonesia yang kemudian terwujud dalam Pancasila adalah alat yang ampuh untuk mengusir penjajah atau kolonialisme. 
Untuk sampai pada bagaimana nasionalisme dalam konteks keIndonesia-an, sebelumnya perlu diketahui proses terwujudnya konsep nasionalisme. Diketahui bahwa secara umum nasionalisme berarti suatu paham, yang berpendapat bahwa kesetiaan tertinggi individu harus diserahkan kepada negara kebangsaan. Perasaan sangat mendalam akan suatu ikatan yang erat dengan tanah tumpah darahnya, dengan tradisi-tradisi setempat dan penguasa-penguasa resmi di daerahnya selalu ada di sepanjang sejarah dengan kekuatan yang berbeda-beda. Akan tetapi, baru pada akhir abad ke-18 M nasionalisme dalam arti kata modern menjadi suatu perasaan yang diakui secara umum. ${ }^{2}$

Benedict Anderson, sebagaimana diungkapkan Sulfikar, melihat nasionalisme sebagai sebuah ide atas komunitas yang dibayangkan, imagined communities. Dibayangkan karena setiap anggota dari suatu bangsa, bahkan bangsa yang terkecil sekalipun, tidak mengenal seluruh anggota dari bangsa tersebut. Nasionalisme hidup dari bayangan tentang komunitas yang senantiasa hadir di pikiran setiap anggota bangsa yang menjadi referensi identitas sosial. Pandangan konstruktivis yang dianut Anderson menarik karena meletakkan nasionalisme sebagai sebuah hasil imajinasi kolektif dalam membangun batas antara kita dan mereka, sebuah batas yang dikonstruksi secara budaya melalui kapitalisme percetakan. ${ }^{3}$

\footnotetext{
${ }^{2}$ Hans Kohn, (1984), Nasionalisme Arti dan Sejarahnya, Terj. Sumantri Mertodipuro, Jakarta: Erlangga, hlm. 11.

${ }^{3}$ Sulfikar Amir, "Epistemologi Nasionalisme”, http://kompas.com/kompascetak/0411/03/Bentara/1363295.htm
} 
Fenomena nasionalisme sebenarnya relatif baru. Ini bisa ditelusuri dari sejarah munculnya konsep bangsa-negara di Eropa sekitar abad ke-18 yang merupakan bagian dari gelombang revolusi kerakyatan dalam meruntuhkan hegemoni kelas aristokrat. Pembacaan sejarah yang demikian memberi indikasi asal-muasal nasionalisme sebagai anak modernitas yang lahir dari rahim "pencerahan", suatu revolusi berpikir yang membawa semangat egaliterianisme. Namun, konsep nasionalisme tidak hanya meliputi aspekaspek kegemilangan dari gagasan modernitas yang ditawarkan oleh Pencerahan Eropa karena ia merupakan akibat (by-product) dari pengkondisian modernitas bersamaan dengan transformasi sosial masyarakat Eropa pada saat itu. ${ }^{4}$

Sartono mengungkapkan, tidak dapat disangkal bahwa di negeri-negeri Asia pada zaman modern, nasionalisme merupakan hasil yang paling penting dari pengaruh kekuasaan Barat. Tentu saja nasionalisme di negeri-negeri Asia dan khususnya di Indonesia tidak dapat disamakan dengan di Barat, karena ia merupakan suatu gejala historis yang telah berkembangan sebagai jawaban terhadap kondisi politik, ekonomi, dan sosial khususnya yang ditimbulkan oleh situasi kolonial. Hal yang esensial bahwa nasionalisme dan kolonialisme itu tidak terlepas satu sama lain, dan terasa juga adanya pengaruh timbal balik antara nasionalisme yang sedang berkembang dan politik kolonial dengan

${ }^{4} I b i d$. 
idiologinya, yang menganggap bahwa peradaban Barat itu lebih tinggi dan berbeda sama sekali dengan kebudayaan Timur. $^{5}$

Jadi, jelas bahwa nasionalisme Indonesia, tidak bisa disamakan dengan nasionalisme Barat, karena nasionalisme Indonesia adalah nasionalisme yang bersenyawa dengan keadilan sosial, anti kolonialisme, yang oleh Bung Karno disebut socio-nasionalism. Nasionalisme yang demikian adalah nasionalisme yang menghendaki penghargaan, penghormatan, toleransi kepada bangsa atau suku-bangsa lain. Dalam konteks Indonesia, pengalaman penderitaan bersama sebagai kaum terjajah melahirkan semangat solidaritas sebagai satu komunitas yang mesti bangkit dan hidup menjadi bangsa merdeka. Semangat tersebut oleh para pejuang kemerdekaan dihidupkan tidak hanya dalam batas waktu tertentu, tetapi terus-menerus hingga kini dan masa mendatang. ${ }^{6}$

Berbeda dengan nasionalisme Indonesia, nasionalisme Barat adalah nasionalisme yang mengarah ke sovinisme, nasionalisme sempit, yang membenci bangsa atau suku-bangsa lain, menganggap bangsa sendirilah yang paling bagus, paling unggul sesuai dengan individualisme Barat. $^{7}$ Nasionalisme Eropa yang pada kelahirannya menghasilkan deklarasi hak-hak manusia berubah menjadi kebijakan yang didasarkan atas kekuatan dan self interest dan bukan atas kemanusiaan. Dalam perkembangannya nasionalisme Eropa berpindah haluan menjadi persaingan fanatisme nasional antar bangsabangsa Eropa yang melahirkan penjajahan terhadap negeri-negeri yang saat itu

\footnotetext{
${ }^{5}$ Sartono Kartodirdjo, (1999), Pengantar Sejarah Indonesia Baru: Sejarah Pergerakan Nasional dari Kolonialisme Sampai Nasionalisme, Jilid 2. Jakarta: Gramedia, hlm. 58.

${ }^{6}$ M.D. Kartaprawira, “Menegakkan Kembali Ideal Nasionalisme Indonesia”, http://www.korwilpdip.org/6EDITORIAL071002.htm.

${ }^{7}$ Ibid.
} 
belum memiliki identitas kebangsaan (nasionalisme) di benua Afrika, Amerika Latin, dan Asia $^{8}$ termasuk Indonesia.

Selanjutnya, dalam ingatan sejarah bangsa Indonesia, ketika berbicara nasionalisme, yang terbangun atas sikap anti kolonialisme, tentu saja tidak dapat melupakan begitu saja peran golongan intelektual. Sartono menyebutkan bahwa sebagai dampak perkembangan pengajaran di Indonesia tumbuhlah golongan sosial baru yang mempunyai fungsi dan status baru sesuai dengan diferensiasi serta spesialisasi dalam bidang sosial-ekonomi dan pemerintahan. Sekaligus juga tercipta golongan profesional yang sebagai golongan sosial baru tidak mempunyai tempat pada strata menurut stratifikasi sosial masyarakat tradisional. Golongan profesional (kaum intelektual) inilah yang posisi sosialnya memungkinkan mereka berfungsi sebagai protagonis modernisasi pada umumnya dan sebagai perintis nasionalisme khususnya. Sebagai generasi pertama yang menuntut pelajaran sistem Barat, mereka tidak hanya menyerap pengetahuan dari texbook pelbagai bidang pengetahuan, tetapi juga mengalami pendidikan formal yang memolakan sikap baru yang mencakup disiplin sosial, pemikiran rasional, gaya hidup menurut jadwal waktu, dan nilai-nilai lainnya. ${ }^{9}$ Pendidikan Barat telah mengakibatkan suatu kesadaran yang masuk ke dalam, terutama kaum pemuda atau intelektual. Pendidikan Barat sangat menonjol sewaktu, misalnya, tahun 1925 Perhimpunan Indonesia menjelaskan sendiri bahwa studi dari sejarah oleh

\footnotetext{
8“'Sejarah Nasionalisme dan Perspektif Islam”, http://robbani.wordpress.com/2007/08/01/4/

${ }^{9}$ Sartono Kartodirdjo, Pengantar Sejarah Indonesia Baru ...., op. cit., hlm. 81-82.
} 
pemuda Indonesia memperkenalkan perjuangan nasional dari beberapa wilayah dalam sejarah dan membuat kaum intelektual Indonesia berpikir mengenai masa depan Indonesia yang dijajah Belanda. ${ }^{10}$

Memang, sebagaimana diungkapkan, berbicara mengenai kelas atau golongan menengah pribumi awal abad ke-20 di wilayah Hindia Belanda tentu saja tidak terlepas dari pembicaraan golongan intelektual baru (kaum terpelajar atau priyayi profesional). ${ }^{11}$ Golongan menengah inilah yang menurut Wertheim nasionalismenya lebih konsisten, baik di kalangan kelompok-kelomok kecil pedagang maupun di kalangan kelas intelektual yang bekerja dalam bidang pmerintahan dan berbagai kelas usaha Barat. Mereka adalah kelompok perkotaan yang bersaing dalam bidang sosial dan ekonomi dengan kelas atas dengan berbagai kelompok yang sudah mengkonsolidasikan diri mereka dalam berbagai fungsi. Perjuangan kompetitif mereka dengan mudah memperlihatkan bentuk nasionalisme karena kelompok yang mereka serang, orang Cina dan Eropa, sebagian besar berasal dari luar dan menekankan karakteristik tersendiri dalam tingkah laku sosial mereka. ${ }^{12}$

Melalui inisiatif golongan menengahatau intelektual inilah muncul berbagai organisasi pergerakan yang semua pada intinya mempunyai satu tujuan, yaitu ingin merdeka atau membebaskan Indonesia dari belenggu kolonialisme. Di antara beberapa organisasi tersebut adalah Indische

\footnotetext{
${ }^{10}$ Frank Dhont, (2005), Nasionalisme Baru Intelektual Indonesia Tahun 1920-an, Yogyakarta: Gadjah Mada University Press, hlm. 90-91.

${ }^{11}$ J.M. Van Der Kroef, (1954), Indonesia in The Modern World. Bandung: Masa Baru. hlm. 151.

${ }^{12}$ W.F. Wertheim, (1999), Masyarakat Indonesia dalam Transisisi: Studi Perubahan Sosial, Yogyakarta: Tiara Wacana, hlm. 261.
} 
Vereninging (1908) yang berubah menjadi Indonesische Vereninging (1922) dan berubah lagi menjadi Perhimpunan Indonesia (1925), Budi Utomo (1908), Sarekat Islam (1912), Indische Partij (1912), Taman Siswa (1922), Partai Nasional Indonesia (1927), Partai Indonesia (1931), Pendidikan Nasional Indonesia/PNI Baru (1932), dan lainnya. ${ }^{13}$

Yang perlu ditekankan bahwa dalam sejarah Indonesia khususnya, memang nasionalisme cukup penting, misalnya, sebagai ideologi pemersatu untuk melawan penjajah Belanda, atau Jepang. Bisa jadi, kalau orang-orang di kepulauan Nusantara ini tersebar terus dan tidak ada ideologi yang mempersatukan, tentu saja dengan mudah Belanda menguasai terus kepulauan ini. Demikian pula, sangat mungkin orang-orang di kepulauan Nusantara justru saling berperang sendiri. Apalagi, ketika politik Belanda terus menerus memompakan permusuhan dan konflik-konflik. ${ }^{14}$

Pada akhirnya, tinjauan sejarah politik sampai kepada kesimpulan bahwa dorongan nasionalisme yang sekian lama dipupuk dan diperjuangkan berhasil menciptakan sebuah bangsa, sebagai sebuah kesatuan yang membedakan diri dari kesatuan politik lain, dan sebuah negara, sebagai sebuah lembaga kekuasaan. Tinjauan sejarah sosial-kultural dapat pula memperlihatkan bahwa kekuatan daya dorong nasionalisme, yang dilahirkan dalam suasana kebudayaan bazar dari "komunitas orang-orang asing" akhirnya menciptakan sebuah komunitas bangsa. Inilah "komunitas yang

\footnotetext{
${ }^{13}$ Lihat Suhartono, (2001), Sejarah Pergerakan Nasional: Dari Budi Utomo sampai Proklamasi 1908-1945, Yogyakarta: Balai Pustaka.

${ }^{14}$ Alfitra Salam, "Biarlah Nasionalisme Keindonesiaan Punah", http://cdc.eng.ui.ac.id/article/articleview/2495/1/41/
} 
dibayangkan” oleh “para perantau” yang pernah secara konseptual menjadi penghuni “ komunitas orang-orang asing”. Jadi dapat dilihat bahwa proses pembentukan bangsa dan negara Indonesia adalah sebagai pergumulan munculnya nasionalisme yang lain membentuk sebuah bangsa dalam wadah negara yang berdaulat. ${ }^{15}$

Selanjutnya, nasionalisme Indonesia melahirkan Pancasila sebagai ideologi negara. Perjuangan yang lama untuk mencapai kemerdekaan kini telah terwujud. Proklamasi Kemerdekaan 17 Agustus 1945 adalah sebagai puncak perjuangan, dan sekaligus pertanda bahwa Indonesia menyatakan sebagai negara yang berdaulat, merdeka, dan mandiri. Untuk memperkuat itu semua, disahkanlah Undang-Undang Dasar 1945 pada tanggal 18 Agustus, yang menjadi simbol kekuasaan besar yang revolusioner yang mengandung persamaan dan persaudaraan, suatu tanda hari cerah setelah digulingkannya kekuasaan asing. ${ }^{16}$ Demikian pula, dengan disahkannya UUD1945, semangat dan jiwa Proklamasi, yaitu Pancasila, memperoleh bentuk dan dasar hukumnya yang resmi sebagai dasar falsafah Negara Republik Indonesia, yaitu Ketuhanan Yang Maha Esa, Kemanusiaan yang adil dan beradab, Persatuan Indonesia, Kerakyatan yang dipimpin oleh hikmat kebijaksanaan dalam permusyawaratan perwakilan, dan Keadilan sosial bagi seluruh rakyat Indonesia.

\footnotetext{
${ }^{15}$ Taufik Abdullah, (2001), Nasionalisme dan Sejarah, Bandung: Satya Historika, hlm. 66-67.

${ }^{16}$ George Mc Turnan Kahin, (1995), Nasionalisme dan Revolusi di Indonesia, Jakarta: Sinar Harapan, hlm. 175.
} 


\section{Nasionalisme Pancasila}

Secara nyata dapat dilihat bila berbicara Pancasila sebagai dasar negera, maka yang terjadi seharusnya adalah bagaimana negara ini berusaha dengan berbagai upaya untuk menegakkan masyarakat yang berketuhanan, adil dan bermoral, mempunyai jiwa ukhuwah (persaudaraan) atau kebersamaan, demokrasi, dan menciptakan kemakmuran masyarakat sesuai dengan cita-cita para pendiri bangsa ini. Pertanyaanya sudahkah semua itu terlaksana, atau adakah usaha penegakan terhadap terlaksananya nilai-nilai Pancasila dengan sebenar-benarnya. Atau, bahkan sebaliknya banyak kalangan baik itu para pejabat atau masyarakat secara umum menjadi orang yang “munafik” dan berprilaku tidak sesuai dengan cita-cita para pendiri bangsa ini, yaitu menjadi manusia yang mengingkari Pancasila.

Jadi, sudah menjadi suatu keharusan apabila bangunan nasionalisme yang ditegakkan, baik sekarang maupun ke depan sampai waktu yang tidak terbatas, adalah tetap berpegang pada nilai-nilai nasionalisme yang telah diperjuangkan oleh para pendiri bangsa ini. Selanjutnya, perlu dikemukakan bahwa jika menengok ke belakang, nasionalisme yang digunakan sebagai alat pemersatu oleh para pendiri bangsa ini adalah nasionalisme yang mentauladani sifat-sifat Tuhan, cinta akan kedilan, egaliter, dan menghargai hak asasi manusia. Inilah bentuk perwujudan dari nilai-nilai Pancasila. Sekarang, sebagai kritik apa yang telah dilakukan oleh masyarakat bangsa ini, perlu dilihat apakah pengamalan nilai-nilai yang terkandung dalam Pancasila 
sudah tercapai. Oleh karena itu, sekedar pengingat tampaknya perlu diulas kembali makna sila-sila yang ada dalam Pancasila.

Pertama, jika mengkaji makna dari sila “Ketuhanan Yang Maha Esa”, sila ini menunjukkan bahwa apa yang berlaku di negara ini, baik yang mengenai kenegaraan, kemasyarakatan maupun perorangan harus sesuai dengan sifat-sifat Tuhan yang tak terbatas, misalnya Maha Besar, Maha Agung, Maha Pengasih, Maha Penyayang, Maha Mengetahui, Maha Mendengan, dan sebagainya. ${ }^{17}$ Azhar Basyir menyebutkan bahwa sila ini merupakan dasar keruhanian, dasar moral bagi masyarakat Indonesia dalam melaksanakan hidup bernegara dan bermasyarakat. Misalnya, dalam kehidupan bernegara berarti dalam penyelenggaraannya wajib menghargai, memperhatikan, dan menghormati petunjuk-petunjuk Tuhan Yang Maha Esa, dan tidak boleh menyimpangnya. ${ }^{18}$ Jadi jelas bahwa sila ini dapat menjadi dasar untuk memimpin ke jalan kebenaran, keadilan, kebaikan, kejujuran, dan persaudaraan sebagaimana sifat-sifat yang dimiliki Tuhan.

Kedua, sila "Kemanusia Yang Adil dan Beradab” dapat diartikan bahwa bagaimana dengan sila ini masyarakat bangsa Indonesia menjadi manusia yang berpegang pada nilai adil dan berakhlak mulia. Ciri manusia yang adil dan beradab dapat ditunjukkan dalam perbuatan yang tidak hanya mementingkan kehidupan jasmaniyah dan lahiriyah saja, melainkan juga kehidupan rokhani. Demikian pula, yang diutamakan bukan hanya yang

\footnotetext{
${ }^{17}$ Sunoto, (2003), Mengenal Filsafat Pancasila: Pendekatan melalui Metafisika, Logika, dan Etika, Yogyakarta: Hanindita, hlm. 63.

${ }^{18}$ Ahmad Azhar Basyir, (1993), Refleksi Atas Persoalan Keislaman; Seputar Filsafat, Hukum, Politik, dan Ekonomi, Bandung: Mizan, hlm. 246.
} 
menyangkut kepentingan diri pribadi, akan tetapi juga kepentingan masyarakat. ${ }^{19}$ Jelas bahwa sila ini menunjukkan bahwa para pendiri bangsa ini menginginkan di Indonesia ini tegak atau dijunjung tinggi nilai-nilai kemanusiaan, seperti persamaan, keadilan, tenggang rasa, mencintai sesama, kesetiakawanan, dan kemanusiaan.

Ketiga, dari sila "Persatuan Indonesia” tampak bahwa para pendiri bangsa ini sadar bahwa tanpa persatuan dan kesatuan langkah, maka tujuan bersama, yang pada waktu itu dijadikan alat untuk melepaskan dari dari cengkraman kolonialisme, tidak akan terwujud. Mereka juga sadar bahwa masyarakat Indonesia adalah masyarakat yang majemuk dan plural, yaitu masyarakat yang terdiri dari berbagai pulau, suku, bahasa, agama, dan kepercayaan. Sunatullah yang dalam hal ini berarti bahwa keberadaan manusia di muka bumi ini adalah plural, bersuku-suku, dan berbangsa-bangsa yang tidak dapat ditolak keberadaanya telah disadari oleh mereka. Dengan demikian, agar terwujud bangsa yang mandiri dan mempunyai harga diri maka harus tercipta ukhuwah dan persatuan tanpa memandang suku atau keyakinan apa yang dianutnya.

Keempat, dapat dikemukakan bahwa kandungan sila "Kerakyatan Yang Dipimpin oleh Hikmat Kebijaksanaan dalam Permusyawaratan Perwakilan” ini menunjuk pada keharusan adanya kerakyatan atau demokrasi yang tentunya memperhatikan dan menghormati nilai ketuhanan dan agama. Kerakyatan atau demokrasi semacam ini berarti dalam menyelenggarakan

\footnotetext{
${ }^{19}$ Sunoto, op. cit., hlm. 81.
} 
kehidupan bernegara harus dilakukan dengan cara bermusyawarah yang secara moral dapat dipertanggungjawabkan kepada Tuhan. ${ }^{20}$ Misalnya, dalam agama Islam sendiri menganjurkan agar selalu bermusyawarah untuk memecahkan apa pun permasalahannya. Banyak sekali ayat Al-Qur’an yang memerintahkan agar manusia dalam menjalani kehidupannya harus berlandaskan pada musyawarah, diantaranya adalah Surat Al-Syura: 38 yang menyebutkan bahwa,

"Dan bagi orang-orang yang mematuhi seruan Tuhannya dan mendirikan shalat, sedangkan urusan mereka diputuskan dengan musyawarah antara mereka."

Kelima, sila “Keadilan Sosial Bagi Seluruh Rakyat Indonesia” pada umumnya dapat diartikan bahwa setiap orang memperoleh apa yang menjadi haknya dan setiap orang memperoleh bagian yang sama dari kekayaan kita bersama. jadi, membangun keadilan sosial berarti menciptakan strukturstruktur yang memungkinkan terlaksananya keadilan. $^{21}$ Jelas, bahwa konsekuensi yang harus dijalankan adalah kepentingan individu dan kepentingan umum harus dalam suatu keseimbangan yang dinamis, yang harus sesuai dengan keadaan, waktu, dan perkembangan zaman. Dalam prakteknya, keadilan sosial tercapai apabila dapat memelihara kepentingan umum negara sebagai negara, kepentingan umum para warga negara bersama, kepentingan bersama dan kepentingan khusus dari para warga negara secara perseorangan, suku bangsa, dan setiap golongan warga negara. ${ }^{22}$

\footnotetext{
${ }^{20}$ Ahmad Azhar Basyir, op. cit., hlm. 249.

${ }^{21}$ Franz Magnis Suseno, ( 2001), Kuasa dan Moral, Jakarta: Gramedia, hlm. 50-51.

${ }^{22}$ Kaelan, (1996), Filsafat Pancasila, Yogyakarta: Paradigma, hlm. 155-156.
} 
Mengkaji nilai-nilai yang terkandung dalam Pancasila, maka akan tampak amatlah mulya apabila nilai-nilai tersebut dijadikan pegangan bagi manusia sebagai khalifah fi al-ard pada umumnya, dan khususnya bagi masyarakat Indonesia. Jika dikaji, Pancasila memang mengandung nilai-nilai universal, yaitu kebenaran umum. Hal ini menandakan bahwa pengkonsep Pancasila adalah para manusia yang cerdas, manusia mengerti ruang batin masyarakat Indonesia, manusia yang mau belajar dari sejarah, dan sekaligus menjadi aktor perubahan dalam sejarah. Oleh karena itu, alangkah tepatnya apabila nasionalisme yang semestinya dipegang oleh masyarakat Indonesia adalah cinta tanah air yang selalu berpegang pada nilai-nilai Pancasila.

Dalam hal ini, nilai-nilai Pancasila harus benar-benar dijadikan spirit moralisme untuk merekonstruksi desain negara bangsa yang penuh keadaban dan bermartabat. Tampaknya, skarang ini konsep nasionalisme harus segera direka ulang sesuai dengan karakteristik kebangsaan Indonesia mutakhir dengan tetap berpegang pada nilai-nilai yang terkandung dalam Pancasila. Desain isi nasionalisme Indonesia harus dimaknai bahwa nasionalisme Indonesia adalah nasionalisme yang menolak segala bentuk diskriminasi, kedholiman, ${ }^{23}$ penjajahan, penindasan, ketidakadilan, serta pengingkaran atas nilai-nilai ketuhanan, sebagaimana yang terkandung dalam Pancasila.

Sekarang, yang perlu dikaji ulang adalah bagaimana dengan nasionalisme bangsa ini, yang mencakup baik para pejabat yang diberi amanat untuk menjalankan roda pemerintahan, DPR, Jaksa Agung, hakim, polisi, para

\footnotetext{
${ }^{23}$ Tardjo Ragil. "Menasionalismekan Kembali Indonesia”. http://www.freelists.org/archives/ppi/08-2005/msg00339.html
} 
intelektual dan birokrat kampus, dan lainnya. Apakah perilaku mereka sudah mencerminkan berjiwa Pancasila. Sudahkah perilaku mereka semua telah sejalan dengan amanat yang tercantum dalam dasar negara, yaitu Pancasila. Tentu saja, jika semua komponen bangsa ini memegang nasionalisme Pancasila sebagai landasan untuk membangun bangsa ini, maka tidak seharusnya terjadi, apa yang disebut dengan kemiskinan, dikriminasi, korupsi, penjualan aset negara, ilegal loging, dan ketidakadilan.

Tampaknya komponen bangsa ini memang belum sepenuhnya menjalankan atau menganut paham nasionalisme yang berlandaskan Pancasila. Hal ini dapat dilihat bahwa dalam bidang ekonomi para pemegang kebijakan belum menjalankan apa yang diamanatkan Pancasila, karena belum tercipta apa yang disebut dengan “ekonomi keadilan”. Semestinya, untuk menciptakan keadilan dan menghilangkan kemiskinan atau paling tidak menguranginya, maka pemegang kebijakan ekonomi bangsa ini harus menjalankan, sebagaimana disinggung Murbyanto, ${ }^{24}$ yaitu prinsip ekonomi koperasi dan ekonomi etik. Karena, diketahui bahwa ekonomi koperasi, berbeda dengan ekonomi ortodok, yaitu ekonomi yang mengajarkan cara-cara bekerja sama bukan cara-cara bersaing. Di sisi lain, jika ekonomi etik yang dipegang, maka keserakahan akan alam benda tidak akan terjadi. Dalam hal ini, jika ekonomi koperasi mengajarkan cara-cara manusia bekerjasama dalam memenuhi kebutuhan dengan sebaik-baiknya, maka ekonomi etik

\footnotetext{
${ }^{24}$ Murbyanto, (2004), Neoliberalisme dan Krisis Ilmu Ekonomi, Yogyakarta: Aditya Media, hlm. 22-23.
} 
mengajarkan perilaku manusia dalam memenuhi kebutuhan etikanya dengan berpedoman pada ajaran-ajaran moral agama.

Demikian pula, jika nasionalisme Pancasila yang dijadikan pegangan, maka ilegal loging, baik di Sumatra (Riau) maupun di Irian Jaya tidak akan terjadi. Karena, jelas bahwa hal semacam itu tidak hanya merusak hutan, akan tetapi para pelaku adalah tergolong orang-orang yang mementingkan diri sendiri dan merugikan seluruh masyarakat Indonesia. Sebagaimana disampaikan oleh Sekjen Lembaga Pengkajian Hutan Indonesia (LPHI) Riau, Andreas Herry Kahuripan, kepada Metro Riau, Selasa, 24 Januari 2006, di Pekanbaru, bahwa ilegal loging di Riau sudah seperti pelacur. Kendati sudah mulai di berantas sejak tahun 1990 lalu, namun hingga kini belum menunjukkan hasil memuaskan. ${ }^{25}$ Tampaknya kesulitan dalam rangka penghentian tindakan penebangan kayu liar ini, karena pada dasarnya para pejabat negeri inilah yang melakukannya.

Banyak kasus lain yang dapat diungkapkan dan merupakan tindakan tidak Pancasilais. Misalnya, tindakan penjualan aset Indosat ke Singapura, atau menjual kekayaan negara ke negara-negara maju, seperti dalam kasus Blok Cepu dan masalah Freeport. Dalam kasus semacam ini, kekayaan negara dikeruk dan dikelola oleh mereka, sementara dalam kenyataannya bangsa ini hanya kebagian sedikit saja. Dengan demikian, sebagaimana dikatakan, bangsa ini yang sebenarnya sebagai pemilik lautan "dolar", hanya bisa puas

\footnotetext{
25”Provinsi Riau: Gagal Berantas Ilegal Loging”, Jumat, 03 Februari 2006, http://www.depdagri.go.id/konten.php?nama=BeritaDaerah\&op=detail_berita_daerah\&id=21
} 
kebagian ampasnya. Orang lain bermewah-mewahan dari hasil penjualan aset kita, sementara rakyat kita hanya bisa melihatnya sambil gigit jari. ${ }^{26}$

Demikian pula, korupsi yang merupakan simbol ketidakadilan seharusnya dapat dihentikan dan bahkan berhenti dengan sendirinya apabila manusia Indonesia ini sadar bahwa Pancasila dasar adalah moral yang harus dipegangi. Mengapa penyakit yang satu ini tampak sulit untuk disembuhkan, dan bahkan sekarang ini menu korupsi seakan menjadi sajian berita yang tiada henti. Orde Reformasi yang diharapkan dapat mengoreksi, justru semakin melembagakan praktik culas elite penguasa. Perilaku korupsi bahkan telah menjamah di semua level instansi pemerintahan bangsa ini. ${ }^{27}$

\section{Kesimpulan}

Dapat ditegaskan bahwa apabila belajar dari sejarah yang pernah terjadi, nasionalisme Indonesia adalah bentuk perwujudan dari sikap dan tindakan yang anti terhadap praktek-praktek kolonialisme. Dengan demikian, nasionalisme Indonesia merupakan suatu bangunan suatu negara yang dibentuk berdasarkan anti penjajahan, penindasan, diskriminasi, kedholiman, ketidakadilan, serta pengingkaran atas nilai-nilai ketuhanan. Tentru saja, apabila masyarakat Indonesia atau person berprilaku dan bertindak dengan sikap-sikap sebagaimana disebutkan tentu saja mereka bukanlah manusia

\footnotetext{
${ }^{26}$ Abu Farhan, “Menjual Negara”, April 02, 2006, http://selayar.blogspot.com/2006_04_01_archive.html

${ }^{27}$ Tardjo Ragil, op. cit.
} 
Indonesia yang mempunyai jiwa nasionalisme sekaligus manusia yang tidak Pancasilais.

\section{DAFTAR PUSTAKA}

Abu Farhan, "Menjual Negara”, http://selayar.blogspot.com/2006_04_01_archive.html.

Ahmad Azhar Basyir, (1993), Refleksi Atas Persoalan Keislaman; Seputar Filsafat, Hukum, Politik, dan Ekonomi, Bandung: Mizan.

Alfitra Salam, "Biarlah Nasionalisme Keindonesiaan Punah”, http://cdc.eng.ui.ac.id/article/articleview/2495/1/41/

Frank Dhont, (2005), Nasionalisme Baru Intelektual Indonesia Tahun 1920-an, Yogyakarta: Gadjah Mada University Press.

Franz Magnis Suseno, ( 2001), Kuasa dan Moral, Jakarta: Gramedia.

George Mc Turnan Kahin, (1995), Nasionalisme dan Revolusi di Indonesia, Jakarta: Sinar Harapan.

Hans Kohn, (1984), Nasionalisme Arti dan Sejarahnya, Terj. Sumantri Mertodipuro, Jakarta: Erlangga.

Kaelan, (1996), Filsafat Pancasila, Yogyakarta: Paradigma.

Kartaprawira, M.D., "Menegakkan Kembali Ideal Nasionalisme Indonesia”, http://www.korwilpdip.org/6EDITORIAL071002.htm.

Murbyanto, (2004), Neoliberalisme dan Krisis Ilmu Ekonomi, Yogyakarta: Aditya Media.

”Provinsi Riau: Gagal Berantas Ilegal Loging”, Jumat, 03 Februari 2006, http://www.depdagri.go.id/konten.php?nama=BeritaDaerah\&op=detail_be rita_daerah\&id=21

Sartono Kartodirdjo, (1999), Pengantar Sejarah Indonesia Baru: Sejarah Pergerakan Nasional dari Kolonialisme Sampai Nasionalisme, Jilid 2. Jakarta: Gramedia.

\section{Nasionalisme dan Negara Kesatuan, Yogyakarta: Kanisius.}

"Sejarah Nasionalisme dan Perspektif Islam”, http://robbani.wordpress.com/2007/08/01/4/ 
Suhartono, (2001), Sejarah Pergerakan Nasional: Dari Budi Utomo sampai Proklamasi 1908-1945, Yogyakarta: Balai Pustaka.

Sulfikar Amir, “Epistemologi Nasionalisme”, http://kompas.com/kompascetak/0411/03/Bentara/1363295.htm

Sunoto, (2003), Mengenal Filsafat Pancasila: Pendekatan melalui Metafisika, Logika, dan Etika, Yogyakarta: Hanindita.

Tardjo Ragil. “Menasionalismekan Kembali Indonesia”. http://www.freelists.org/archives/ppi/08-2005/msg00339.html

Taufik Abdullah, (2001), Nasionalisme dan Sejara,. Bandung: Satya Historika.

Van Der Kroef, J.M., (1954), Indonesia in The Modern World. Bandung: Masa Baru.

Wertheim, W.F., (1999), Masyarakat Indonesia dalam Transisisi: Studi Perubahan Sosial, Yogyakarta: Tiara Wacana. 